\title{
Hypoprolactinemia as a Clue to Diagnosis of Mild Central Hypothyroidism due to IGSF1 Deficiency
}

\author{
(D) Anastasios Papadimitriou, (D) Anna Papadopoulou, (D) Kleanthis Kleanthous, (D) Dimitrios T. Papadimitriou, \\ (D) Vassiliki Papaevangelou
}

National and Kapodistrian University of Athens, "Attikon" University Hospital, Third Department of Pediatrics, Athens, Greece

\begin{abstract}
What is already known on this topic?
IGSF1 deficiency has been recently found to be an X-linked cause of central hypothyroidism (CeH). Additionally patients may present hypoprolactinemia, obesity, transient partial growth hormone deficiency, delayed adrenarche, normal timing of testicular enlargement but delayed testosterone rise in puberty resulting in delayed adolescent growth spurt, and adult macro-orchidism.
\end{abstract}

\section{What this study adds?}

We present an asymptomatic boy with mild CeH due to a novel mutation of IGSF1 gene. He mostly had low normal FT4 levels while PRL was undetectable. If he had not had his PRL levels measured most probably diagnosis would be missed.

\begin{abstract}
Loss-of-function mutations of IGSF1 are an X-linked cause of central hypothyroidism (CeH) and hypoprolactinemia. A boy who is now 15.2 years old presented at the age of 7.69 years for evaluation of obesity. Previous thyroid function evaluation suggested CeH [FT4 $0.6 \mathrm{ng} / \mathrm{mL}$, thyroid-stimulating hormone (TSH) $2.2 \mathrm{mIU} / \mathrm{L}]$ but his physician took no action. At presentation he was clinically and biochemically euthyroid, prepubertal and obese. Serum prolactin (PRL) was undetectable. Biochemistry was normal except for mild hypercholesterolemia, total cholesterol $198 \mathrm{mg} / \mathrm{dL}$. Subsequently FT4 and TSH levels fluctuated between 0.72-0.95 ng/dL (normal 0.82.0) and 1.94-5.77 mIU/L (normal 0.3-5.0), respectively. Sequencing of IGSF1 gene revealed a novel genetic change c.3805C > T in exon 19; substitution of amino acid Arginine at position 1269 with a premature «stop» codon resulting in an altered protein product. The patient additionally presented delayed adrenarche, low height velocity that resolved spontaneously and normal pubertal onset associated with increased FSH levels. At 14 years-of-age, while the patient was at Tanner stage 4, PRL levels became detectable, rising gradually to $2.3 \mathrm{ng} / \mathrm{mL}$ at last examination. Thyroxine replacement therapy resulted in decrease in total cholesterol $103 \mathrm{mg} / \mathrm{dL}$. A high index of suspicion for the disorder is needed since several measurements of thyroid function may be required for CeH to be disclosed. The patient's normal FT4 levels and normal intelligence would have resulted in a missed diagnosis if the serum PRL levels had not been measured. This case highlights the importance of measuring PRL in a boy with low normal FT4 and normal TSH levels.
\end{abstract}

Keywords: Central hypothyroidism, hypoprolactinemia, IGSF1

\section{Introduction}

Loss-of-function mutations of the immunoglobulin superfamily, member 1 (IGSF1) gene have been recently described as an X-linked cause of congenital central hypothyroidism $(\mathrm{CeH})(1)$, with an estimated prevalence of $1 / 100000$ (2). $\mathrm{CeH}$ is the hallmark of the disorder, however, patients additionally may present with hypoprolactinemia, transient partial growth hormone (GH) deficiency (GHD), normal timing of testicular enlargement but delayed testosterone rise in puberty resulting in delayed adolescent growth spurt, and adult macro-orchidism (3). The IGSF1 gene resides on the X-chromosome and thus its mutations affect mainly males, although female heterozygous carriers may present with $\mathrm{CeH}$ (3). The prevalence of low FT4 in female carriers is reported to be $18 \%$ (4). The IGSF1 gene encodes an immunoglobulin superfamily glucoprotein of the plasma membrane and the IGSF1 protein was 
observed in somatotropes, thyrotropes, and lactotropes of anterior pituitary, whereas it was absent in gonadotropes or corticotropes. Moreover, the IGSF1 protein is predominantly expressed in testis, muscle, heart and pancreas.

We present a boy with mild $\mathrm{CeH}$ due to a novel mutation of the IGSF1 gene. Additionally, the patient presented with undetectable prolactin (PRL) levels, that proved to be the clue to diagnosis.

\section{Case Report}

A boy of Greek descent, who is currently 15.2 years old, presented to our pediatric endocrinology clinic at the age of 7.69 years for obesity evaluation. He is the first child of unrelated parents, born after normal delivery with normal body weight and length. Developmental milestones were achieved at a normal age. During the preschool years he had normal height velocity but increase in body weight. Thyroid function tests (TFT) ordered by his pediatrician, at 3 and 4 years-of-age, were compatible with $\mathrm{CeH}$ (FT4 $0.5 \mathrm{ng} / \mathrm{mL}$, thyroid-stimulating hormone (TSH) $2.2 \mathrm{mIU} / \mathrm{L}$ and FT4 0.65 $\mathrm{ng} / \mathrm{mL}$, TSH $1.8 \mathrm{mIU} / \mathrm{L}$, respectively), however, no action was taken. His parents and siblings (a girl and twin boys currently 13 and 9.5 years old, respectively) are healthy. Mother did not breast-feed any of her four children because of inadequate milk production.

At presentation, the patient's height standard deviation score (HSDS) was $122.5 \mathrm{~cm}$ (HSDS -0.55). He was prepubertal and euthyroid, with no typical symptoms of hypothyroidism such as fatigue, constipation, or bradycardia. His weight was $35.1 \mathrm{~kg}$ (WSDS 1.67), body mass index (BMI) $23.4 \mathrm{~kg} /$ $\mathrm{m}^{2}$ (BMI-SDS 2.89). The thyroid gland was non-palpable. School performance was reported as very good. Target height (TH) SDS was +1.1.

TFT showed FT4 $1.0 \mathrm{ng} / \mathrm{dL}$ (0.8-2.0), TSH $1.98 \mathrm{mIU} / \mathrm{L}$ (0.3-5.0), PRL $<0.7 \mathrm{ng} / \mathrm{mL}$ (3-18), insulin like growth factor 1 (IGF1) 126 $\mathrm{ng} / \mathrm{mL}$ (110-565) and bone age was 6.7 years. Biochemistry was normal except for a mild increase in total cholesterol 198 mg/dL ( < 170), high-density lipoprotein (HDL)-cholesterol 68 $\mathrm{mg} / \mathrm{dL}$ ( $>40$ ), low-density lipoprotein (LDL)-cholesterol 123 $\mathrm{mg} / \mathrm{dL}$ ( < 129) and triglycerides $36 \mathrm{mg} / \mathrm{dL}$ ( < 150). During the next two years there was fluctuation of FT4 levels between 0.72-0.95 ng/dL, of TSH levels between 1.94-5.77 mIU/L, whereas PRL was always undetectable. Thyrotropin releasing hormone (TRH) test showed a normal TSH response, 0':3.44 mIU/L, 30':14.73 mIU/L, 60':11.71 mIU/L, and an abnormal PRL response 0': <0,4 ng/mL, 30': 1.7 ng/mL, 60': 0.9 ng/ $\mathrm{mL}$. Basal PRL levels became detectable at $1.7 \mathrm{ng} / \mathrm{mL}$ at the age of 14 years, at Tanner stage 4, increasing slightly to $2 \mathrm{ng} /$ $\mathrm{mL}$ and $2.3 \mathrm{ng} / \mathrm{mL}$ at the age of 14.7 years and 15.2 years, respectively. Thyroid ultrasonography revealed a hypoplastic thyroid gland, total thyroid volume $2.1 \mathrm{~mL}$ and $2.2 \mathrm{~mL}$ at 9 and 15.2 years-of-age, respectively.

At 9.8 years, due to low height velocity (Figure 1), a GH stimulation with glucagon was performed that showed a

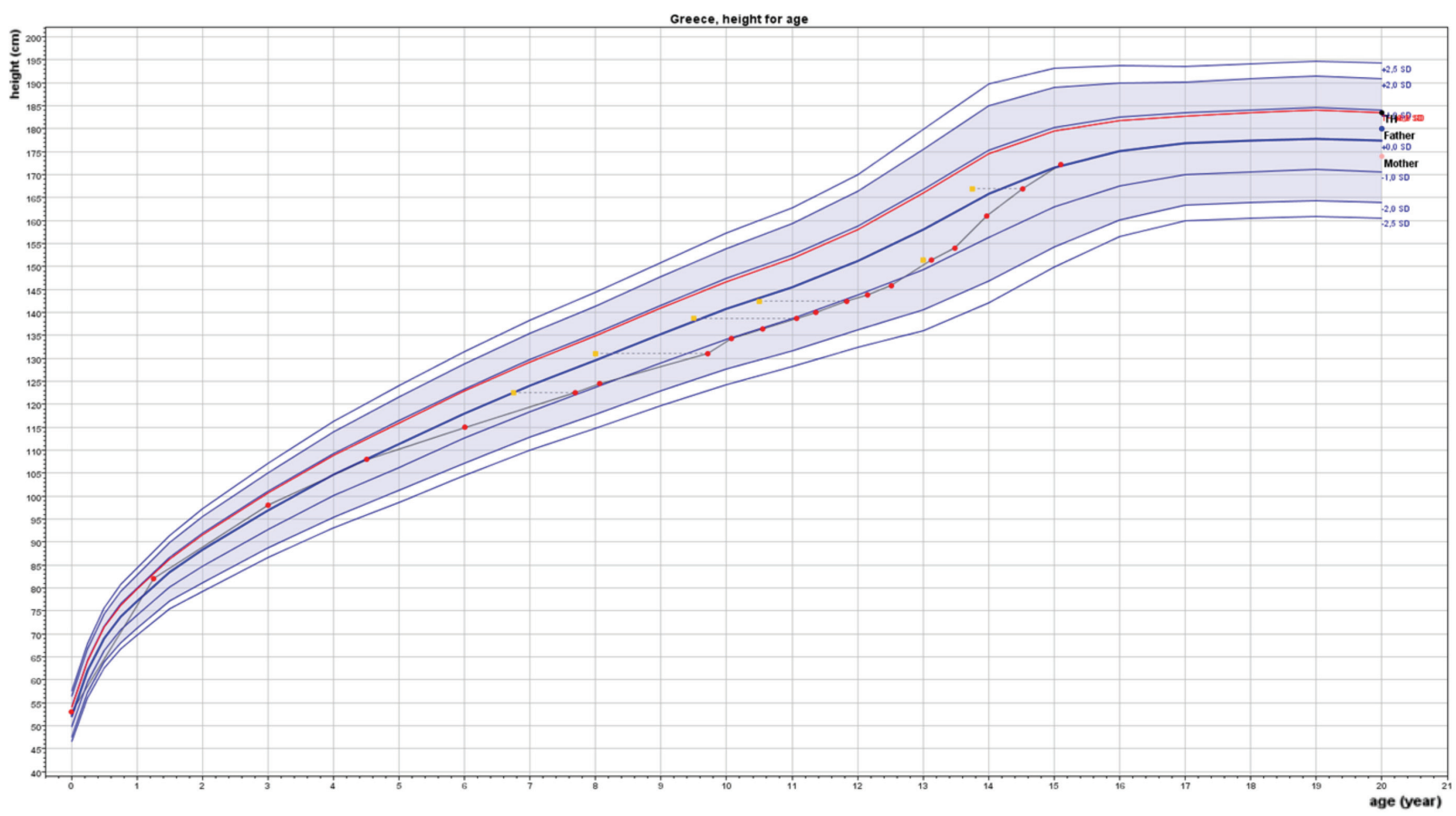

Figure 1. Progression of height. Height velocity normalized spontaneously after the age of 10 years. Squares denote bone ages. Arrow depicts initiation of L-thyroxine treatment 
subnormal peak level of serum GH $4.7 \mathrm{ng} / \mathrm{mL}$ and normal peak serum cortisol $25.7 \mu \mathrm{g} / \mathrm{dL}$ (normal $>18 \mu \mathrm{g} / \mathrm{dL}$ ). Serum IGF1 was 116 ng/mL (normal 110-565). Brain MRI showed a normal pituitary. Soon afterwards the boy presented with spontaneous normalization of height velocity and we therefore suspended further testing of the GH axis. At the age of 11 years thyroxine replacement was started, his FT4 being a little below normal $0.7 \mathrm{ng} / \mathrm{dL}$, which resulted in undetectable TSH. Normalization of FT4 had no substantial difference in the boy's general well-being nor in his growth parameters (height, BMI), however it was associated with a substantial decrease in lipid levels, total cholesterol $103 \mathrm{mg} /$ dL, HDL-cholesterol $51 \mathrm{mg} / \mathrm{dL}$, LDL-cholesterol $45 \mathrm{mg} / \mathrm{dL}$, triglycerides $37 \mathrm{mg} / \mathrm{dL}$.

The boy entered puberty at 12 years of age. FSH levels were increased at 9.3 to $11.4 \mathrm{mIU} / \mathrm{mL}$, during prepuberty and early puberty, whereas LH levels were normal. At last examination, at the age of 15.2 years serum FSH was still increased (15.3 mIU/mL) with normal testicular volume (TV) of $18 \mathrm{~mL}$. Testosterone levels were $<10 \mathrm{ng} / \mathrm{mL}$ until TV 12 $\mathrm{mL}$. At last examination testosterone levels were $451 \mathrm{ng} /$ $\mathrm{dL}$, being low normal for a TV of $18 \mathrm{~mL}$. Moreover, the boy presented with delayed biochemical adrenarche [serum dehydroepiandrosterone sulfate (DHEAS) being $12 \mathrm{ng} / \mathrm{mL}$ at the age of 7.8 years, $16.1 \mathrm{ng} / \mathrm{mL}$ at the age of 9.9 years, 36 $\mathrm{ng} / \mathrm{mL}$ at the age of 11.8 years and $75 \mathrm{ng} / \mathrm{mL}$ at 12.5 years of age] and delayed pubarche at 13 years of age. The patient also exhibited a delayed onset of pubertal growth spurt, at about 13 years of age when TV was $13.5 \mathrm{~mL}$.

Height velocity is normal, as are serum IGF1 levels at 316 $\mathrm{ng} / \mathrm{mL}$ (152-540), and predicted adult height is within TH.

TFT of his mother showed normal levels of T4 $6.24 \mu \mathrm{g} / \mathrm{dL}$, TSH $2.97 \mathrm{mIU} / \mathrm{L}$, as well as PRL $8.5 \mathrm{ng} / \mathrm{mL}$. His twin brothers also had normal TFT and PRL, brother 1: FT4 1.34 ng/dL, TSH $2.80 \mathrm{mIU} / \mathrm{L}$, PRL $3.6 \mathrm{ng} / \mathrm{mL}$ and brother 2: FT4 $1.44 \mathrm{ng} /$ dL, TSH $2.87 \mathrm{mIU} / \mathrm{L}$, PRL $4.5 \mathrm{ng} / \mathrm{mL}$.

\section{Molecular Analysis}

Analysis of IGSF1 gene revealed a genetic change, c. 3805C > T in exon 19 (Figure 2), that resulted in substitution of amino acid Arginine at position 1269 with a "stop" codon and the production of an altered protein product. This genetic change has not been reported previously in patients with $\mathrm{CeH}$. We also performed analysis of the gene in the boy's mother and sister. His mother was found to carry the same mutation as the proband, but no mutation was found in his sister. IGSF1 gene analysis was not performed in his brothers because of normal thyroid function in both of them.

\section{Discussion}

We identified a novel IGSF1 nonsense mutation in a Greek patient with congenital $\mathrm{CeH}$. The molecular defect observed in our patient (p.Arg1269X) prematurely truncates the IGSF1 protein at the end of the $12^{\text {th }}$ Ig loop in the extracellular portion of the C-terminal domain. The IGSF1 protein includes 12 Ig-like domains in two sets of five and seven motifs separated by a linker region, followed by a transmembrane domain and a short cytoplasmic tail (5). The N-terminal segment undergoes translational proteolysis while the C-terminal is expressed extracellularly at the plasma membrane. The precise molecular role of IGSF1 remains unclear.

To date, more than 30 distinct mutations have been described including missense, nonsense, frameshift and whole gene deletions $(6,7)$ that lead to loss of protein function. All but one of the reported mutations are located in the C-terminal domain of the protein and impair IGSF1 trafficking from the endoplasmic reticulum to the plasma membrane. There is no clear genotype-phenotype correlation, while variation in the extent of hypothyroidism or the other clinical features, even within families, has been reported $(8,9)$.

IGSF1 is expressed in thyrotrope cells of the anterior pituitary. IGSF1-deficient male mice have reduced serum TSH and decreased pituitary Trhr mRNA levels (1), while others have shown that the principal impairment is attenuated TRH actions in pituitary thyrotropes (10). Garcia et al (11), in a patient with severe congenital $\mathrm{CeH}$ due to complete deletion of the IGSF1 gene, described markedly decreased TSH bioactivity, poor response to TRH stimulation and decreased TRHR expression. Our patient showed a normal

\section{a}

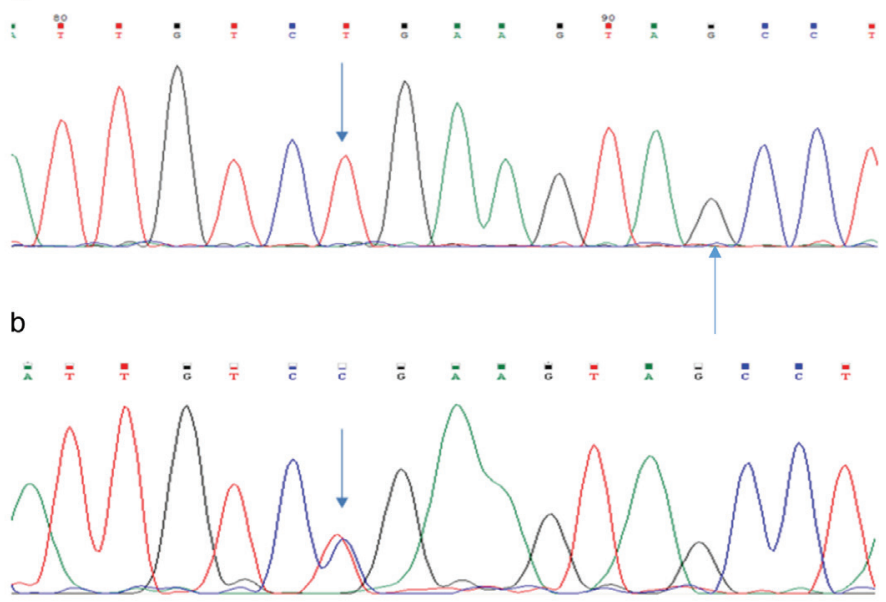

Figure 2. Sequencing of the IGSF1 gene showing the c.3805C > T (p.Arg1269Ter) genetic change in exon 19: (a) patient, (b) mother 
TSH response to TRH stimulation, suggesting impaired endogenous TRH action. Moreover, he had a hypoplastic thyroid gland, a finding observed in $74 \%$ of IGSF1 deficient patients (4).

IGSF1 protein is detected in pituitary lactotropes, however PRL deficiency is present in about $67 \%$ of IGSF1-deficient patients (3). No explanation for normal PRL levels has been given. Our patient had undetectable serum PRL, and very poor PRL response to TRH stimulation suggesting pituitary dysfunction. However, basal PRL levels became detectable at the age of 14 years showing a gradual increase. It remains to be seen whether PRL will normalize as the child grows older.

Increased birth weight or length is observed in a substantial number of patients (12). $67 \%$ of IGSF1-deficient male children were classified as overweight and $21 \%$ as obese (4), being in accord with the phenotype of our patient. It is unclear how these metabolic alterations are related to IGSF1 deficiency.

Children with IGSF1 deficiency present with disharmonious pubertal development, that is pubertal onset at a normal age but delayed testosterone increase occurring at an advanced TV. In adult life testosterone levels are usually low or low normal. Late adolescent and adult patients commonly present with macro-orchidism, however, TV may be normal (13) or increased from the prepubertal years. Our patient entered puberty at a normal age. At onset of puberty the patient's basal FSH levels were increased, LH concentrations were normal for pubertal onset and showed a normal progression according to pubertal status, whereas testosterone levels in early puberty were low for TV but normalized as puberty progressed. It is not clear what causes the disharmonious pubertal development in these patients.

Patients with IGSF1 deficiency have been reported to present with delayed adrenarche (14). Our patient presented with the marker of biochemical adrenarche, that is serum DHEAS $\geq 40 \mu \mathrm{g} / \mathrm{dL}$, after the age of 12 years and pubarche at the age of 13 years. The median age of pubic hair development for Greek boys is 11.2 years (15).

Transient partial GH deficiency has been reported in a subset of patients with IGSF1 deficiency. It is not clear why our patient exhibited growth deceleration, although subnormal GH secretion, low normal IGF1 levels and the delayed bone age might suggest transient GH deficiency that resolved before adolescence. The period between 6 and 11 years of age in boys constitutes the juvenile phase of growth characterized by growth deceleration relative to the preceding childhood phase and by increase of adrenal androgens (adrenarche) (16). Based on the very low DHEAS levels of our patient during this period we can speculate that low adrenal androgens may exaggerate the normal growthdecelerating pattern of the juvenile period. Normalization of height velocity, which occurred prior to thyroid hormone substitution, might be attributed to the gradual increase of adrenal androgens

\section{Conclusion}

In conclusion, we present a male patient with $\mathrm{CeH}$ and PRL deficiency due to a novel mutation of the IGSF1 gene. Additionally, he presented with obesity, disharmonious puberty, and delayed adrenarche which are all features of the IGSF1 syndrome. The patient had mostly low normal FT4 levels, thus PRL deficiency was the clue to diagnosis. Most reported cases of $\mathrm{CeH}$ due to IGSF1 deficiency are symptomatic necessitating L-thyroxine replacement. We believe, however, that a significant number of patients are undetected because symptoms may be absent or subtle. Diagnosis is important for genetic consultation, since no clear genotype-phenotype correlation is observed, even within the same family. Furthermore, with TSH-based neonatal congenital hypothyroidism screening programs neonatal diagnosis will be missed and definitive diagnosis is likely to be delayed. Children of female carriers and female children of male patients should be screened in neonatal life for FT4 and TSH levels. This case highlights the importance of determining PRL levels in a boy with low normal FT4 and normal TSH levels.

\section{Ethics}

Informed Consent: Consent form was filled out by all participants.

Peer-review: Externally and internally peer-reviewed.

\section{Authorship Contributions}

Surgical and Medical Practices: Anastasios Papadimitriou, Anna Papadopoulou, Kleanthis Kleanthous, Concept: Anastasios Papadimitriou, Anna Papadopoulou, Design: Anastasios Papadimitriou, Anna Papadopoulou, Vassiliki Papaevangelou, Data Collection or Processing: Kleanthis Kleanthous, Dimitrios Papadimitriou, Analysis or Interpretation: Anastasios Papadimitriou, Anna Papadopoulou, Literature Search: Kleanthis Kleanthous, Dimitrios Papadimitriou, Writing: Anastasios Papadimitriou, Anna Papadopoulou, Vassiliki Papaevangelou.

Financial Disclosure: The authors declared that this study received no financial support. 


\section{References}

1. Sun Y, Bak B, Schoenmakers N, van Trotsenburg AS, Oostdijk W, Voshol P, Cambridge E, White JK, le Tissier P, Gharavy SN, MartinezBarbera JP, Stokvis-Brantsma WH, Vulsma T, Kempers MJ, Persani L, Campi I, Bonomi M, Beck-Peccoz P, Zhu H, Davis TM, Hokken-Koelega AC, Del Blanco DG, Rangasami JJ, Ruivenkamp CA, Laros JF, Kriek M, Kant SG, Bosch CA, Biermasz NR, Appelman-Dijkstra NM, Corssmit EP, Hovens GC, Pereira AM, den Dunnen JT, Wade MG, Breuning MH, Hennekam RC, Chatterjee K, Dattani MT, Wit JM, Bernard DJ. Loss-offunction mutations in IGSF1 cause an X-linked syndrome of central hypothyroidism and testicular enlargement. Nat Genet 2012;44:13751381. Epub 2012 Nov 11

2. Joustra SD, van Trotsenburg AS, Sun Y, Losekoot M, Bernard DJ, Biermasz NR, Oostdijk W6, Wit JM. IGSF1 deficiency syndrome: a newly uncovered endocrinopathy. Rare Dis 2013;1:e24883.

3. Joustra SD, Schoenmakers N, Persani L, Campi I, Bonomi M, Radetti G, Beck-Peccoz P, Zhu H, Davis TM, Sun Y, Corssmit EP, AppelmanDijkstra NM, Heinen CA, Pereira AM, Varewijck AJ, Janssen JA, Endert E, Hennekam RC, Lombardi MP, Mannens MM, Bak B, Bernard DJ, Breuning $\mathrm{MH}$, Chatterjee K, Dattani MT, Oostdijk W, Biermasz NR, Wit JM, van Trotsenburg AS. The IGSF1 deficiency syndrome: characteristics of male and female patients. J Clin Endocrinol Metab 2013;98:4942-4952. Epub 2013 Oct 9

4. Joustra SD, Heinen CA, Schoenmakers N, Bonomi M, Ballieux BE, Turgeon MO, Bernard DJ, Fliers E, van Trotsenburg AS, Losekoot M, Persani L, Wit JM, Biermasz NR, Pereira AM, Oostdijk W; IGSF1 Clinical Care Group. IGSF1 Clinical Care Group. IGSF1 Deficiency: Lessons from an extensive case series and recommendations for clinical management. J Clin Endocrinol Metab 2016;101:1627-1636. Epub 2016 Feb 3.

5. Frattini A, Faranda S, Redolfi E, Allavena P, Vezzoni P. Identification and genomic organization of a gene coding for a new member of the cell adhesion molecule family mapping to Xq25. Gene 1998;214:1-6.

6. Bernard DJ, Brule' E, Smith CL, Joustra SD, Wit JM. From Consternation to Revelation: Discovery of a Role for IGSF1 in Pituitary Control of Thyroid Function. J Endocr Soc 2018;2:220-231.

7. Peters C, Van Trotsenburg ASP, Schoenmakers N. DIAGNOSIS OF ENDOCRINE DISEASE: Congenital hypothyroidism: update and perspectives. Eur J Endocr 2018;179:297-317.

8. Hughes JN, Aubert M, Heatlie J, Gardner A, Gecz J, Morgan T, Belsky $\mathrm{J}$, Thomas PQ. Identification of an IGSF1-specific deletion in a five- generation pedigree with X-linked Central Hypothyroidism without macroorchidism. Clini Endocrinol (Oxf) 2016;85:609-615. Epub 2016 Jun 9

9. Roche EF, McGowan A, Koulouri O, Turgeon MO, Nicholas AK, Heffernan E, El-Khairi R, Abid N, Lyons G, Halsall D, Bonomi M, Persani L, Dattani MT, Gurnell M, Bernard DJ, Schoenmakers N. A novel IGSF1 mutation in a large Irish kindred highlights the need for familial screening in the IGSF1 deficiency syndrome. Clin Endocrinol (Oxf) 2018;89:813-823. Epub 2018 Oct 1

10. Turgeon MO, Silander TL, Doycheva D, Liao XH, Rigden M, Ongaro L, Zhou X, Joustra SD, Wit JM, Wade MG, Heuer H, Refetoff S, Bernard DJ. TRH action is impaired in pituitaries of male IGSF1-deficient mice. Endocrinology 2017;158:815-830.

11. García M, Barrio R, García-Lavandeira M, Garcia-Rendueles AR, Escudero A, Díaz-Rodríguez E, Gorbenko Del Blanco D, Fernández A, de Rijke YB, Vallespín E, Nevado J, Lapunzina P, Matre V, Hinkle PM, Hokken-Koelega AC, de Miguel MP, Cameselle-Teijeiro JM, Nistal M, Alvarez CV, Moreno JC. The syndrome of central hypothyroidism and macroorchidism: IGSF1 controls TRHR and FSHB expression by differential modulation of pituitary TGF $\beta$ and Activin pathways. Sci Rep 2017;7:42937.

12. Asakura Y, Abe K, Muroya K, Hanakawa J, Oto Y, Narumi S, Hasegawa T, Adachi M. Combined Growth Hormone and Thyroid-Stimulating Hormone deficiency in a Japanese patient with a novel frameshift mutation in IGSF1. Horm Res Paediatr 2015;84:349-354. Epub 2015 Aug 19

13. Hughes JN, Aubert M, Heatlie J, Gardner A, Gecz J, Morgan T, Belsky $J$, Thomas PQ. Identification of an IGSF1-specific deletion in a fivegeneration pedigree with X-linked central hypothyroidism without macroorchidism. Clin Endocrinol (Oxf) 2016;85:609-615. Epub 2016 Jun 9

14. Van Hulle S, Craen M, Callewaert B, Joustra S, Oostdijk W, Losekoot M, Wit JM, Turgeon MO, Bernard DJ, De Schepper J. Delayed adrenarche may be an additional feature of Immunoglobulin Super Family Member 1 deficiency syndrome. J Clin Res Pediatr Endocrinol 2016;8:86-91. Epub 2015 Dec 18

15. Papadimitriou A, Douros K, Kleanthous K, Papadimitriou DT, Attilakos A, Fretzayas A. Pubertal maturation of contemporary Greek boys: no evidence of a secular trend. J Adolesc Health 2011;49:434-436. Epub 2011 Feb 11

16. Hochberg Z. Juvenility in the context of life history theory. Arch Dis Child 2008;93:534-539. Epub 2008 Mar 12 